\title{
Dinamika Perempuan Berpolitik: Strategi Pengembangan Partai Keadilan Sejahtera di Era Reformasi
}

\author{
Mochamad Parmudi, ${ }^{1}$ \\ Tulus Warsito, ${ }^{2}$ Sidik \\ Jatmika ${ }^{3}$ \\ ${ }^{1}$ Fakultas IImu Sosial dan IImu Politik \\ Universitas Islam Negeri Walisongo \\ Semarang, 2,3Pascasarjana Universitas \\ Muhammadiyah Yogyakarta \\ email:parmudimochamad@yahoo.com
}

\begin{abstract}
Partai Keadilan Sejahtera (PKS) is a unique and phenomenal party, it was born from the womb of a socialreligious movement named Jama'ah Tarbiyah which later morphed into an Islamic political party. The PKS social base is a middle-class, educated and young Muslim community. This research explores the strategy of developing PKS in Kebumen District from 1999 to 2014 in the dynamics of Indonesian Islamic politics. This research reveals the unique phenomenon of PKS Kebumen's role in an electoral manner in the distribution of votes and seats in the Dewan Perwakilan Rakyat Daerah (DPRD). The method of approach uses phenomenological studies. The results of this study are that PKS was born of an ideology, or Islamic religious thought. His birth was acceptable to the community because PKS approached the community through collective actions such as; majlis ta'lim, social services, natural disaster assistance, channeling financial loan funds, establishing school buildings, and places of worship.
\end{abstract}

\section{Keywords: dynamics; Islamic politics; Partai Keadilan Sejahtera; Kebumen}

\begin{abstract}
Abstrak: Partai Keadilan Sejahtera (PKS) adalah partai yang unik dan fenomenal, ia lahir dari rahim gerakan sosial keagamaan bernama Jama'ah Tarbiyah yang kemudian bermetamorfosis menjadi partai politik Islam. Basis sosial PKS adalah masyarakat Muslim kelas menengah, terdidik, dan muda. Penelitian ini mengeksplorasi strategi pengembangan PKS di Kabupaten Kebumen 1999-2014 dalam dinamika politik Islam Indonesia. Penelitian ini mengungkap fenomena unik kiprah PKS Kebumen secara elektoralis dalam persebaran perolehan suara dan kursi anggota Dewan Perwakilan Rakyat Daerah Kabupaten Kebumen. Metode pendekatan menggunakan studi fenomenologis. Hasil penelitian ini adalah bahwa PKS lahir dari sebuah ideologi, atau pemikiran keagamaan Islam. Kelahirannya bisa diterima masyarakat karena PKS melakukan pendekatan ke masyarakat melalui tindakan kolektif seperti majlis ta'lìm, bakti sosial, bantuan bencana alam, menyalurkan dana pinjaman keuangan, mendirikan bangunan sekolah, dan tempat ibadah.
\end{abstract}

Kata Kunci: dinamika; politik Islam; Partai Keadilan Sejahtera; Kebumen 


\section{A. Pendahuluan}

Runtuhnya rezim Orde Baru tahun 1998 tidak saja membuka peluang kebebasan bagi kehidupan politik bangsa Indonesia, tetapi juga menumbuhkan hasrat para tokoh politik, agamawan, pengusaha, dan kalangan intelektual untuk menggapai kekuasaan melalui partai politik. Bagaikan kuda yang lepas dari kandang, antusiasme masyarakat untuk mendirikan partai sangat besar. Hal ini ditandai dengan kenyataan munculnya tidak kurang dari 150 partai politik baru hanya dalam kurun waktu enam bulan, sejak runtuhnya Orde Baru. ${ }^{1}$

Pasca reformasi tahun 1998, terjadi fenomena yang sangat menonjol, yaitu munculnya banyak partai baru di antara partai-partai terdahulu yang ikut dalam verifikasi untuk menjadi peserta pemilihan umum tahun 1999. Pemilu 1999 diikuti oleh empat puluh delapan (48) partai politik. Partai Keadilan (PK) merupakan salah satu kontestan yang berazaskan Islam. Ali Said Damanik mencatat bahwa PK adalah satu-satunya partai politik yang memiliki keunikan karena didukung oleh aktivis dakwah kampus, intelektual muda yang berasal dari lingkungan penganut Islam. ${ }^{2}$ Oleh karena tidak terpenuhinya aturan syarat minimal perolehan suara sah (electoral threshold) sebesar 3\% seperti yang telah ditetapkan dalam Undang-undang Pemilu Nomor 3 Tahun 1999 pada Pemilihan Umum 1999, maka Partai Keadilan untuk dapat mengikuti pemilu 2004 harus metamorphosis (berubah nama) menjadi sebuah partai yang dapat mengakomodasi keinginan kader-kader Partai Keadilan untuk tetap berkontribusi pada perjuangan umat.

Partai Keadilan Sejahtera (selanjutnya ditulis PKS) sebagai partai Islam merupakan fenomena unik dalam arena perpolitikan Indonesia. PKS bermula dari Partai Keadilan yang didirikan pada tanggal 20 Juli 1998 oleh para aktivis kampus (Jama'ah Tarbiyah) dan secara resmi dideklarasikan pada 9 Agustus

'Bambang Setiawan dan Bastian Nainggolan, Partai-partai Politik Indonesia: Ideologi dan Program 2004-2009 (Jakarta: Kompas Gramedia Group, 2004), vii; Muhammad Iqbal dan Amien Hussein Nasution, Pemikiran Politik Islam: dari Masa Klasik Hingga Indonesia Kontemporer, 3 ed. (Jakarta: Kencana Prenada Media, 2010), 298-300.

${ }^{2}$ Ali Said Damanik, Fenomena Partai Keadilan: Transformasi 20 Tahun Gerakan Tarbiyah di Indonesia (Jakarta: Teraju, 2003), xxiii. 
1998. Dalam menghadapi realitas politik Indonesia, PKS cenderung adaptif, dinamis dan lentur kendatipun begitu tetap mengusung gagasan Islam sebagai solusi komprehensif bagi kehidupan berbangsa dan bernegara. ${ }^{3}$

PKS adalah partai yang tidak biasa, ia lahir dari rahim gerakan sosial bernama Jama'ah Tarbiyah yang kemudian bermetamorfosis menjadi partai politik Islam. Basis sosial partai tersebut adalah kelompok Muslim terdidik, muda, dan golongan kelas menengah kota. PKS tampil sebagai "partai kader" yang militansinya cukup tinggi dengan menerapkan standar ketat, disiplin dalam proses rekrutmen dan pelatihan anggota-anggotanya, juga aktif dalam bakti sosial membantu korban bencana alam di Indonesia.

Kaderisasi PKS memiliki fungsi rekrutmen calon anggota dan fungsi pembinaan untuk seluruh anggota, kader, dan fungsionaris partai. Fungsi-fungsi ini dijalankan secara terbuka melalui infra struktur kelembagaan partai yang tersebar dari tingkat pusat hingga tingkat ranting. Fungsionalisasi berjalan sepanjang waktu selaras dengan tujuan dan sasaran umum partai, khususnya dalam bidang penyiapan sumber daya manusia dalam partai. ${ }^{4}$

Pada Pemilu 1999, PK sangat kuat berwarna Islam eksklusivis. Seperti banyak partai Islam lain, kampanye utamanya adalah Islam ideologis seperti pemberlakuan syariat agar negara lebih Islami. Namun Muslim Indonesia tampaknya tidak punya keinginan cukup untuk agenda itu, karena seperti terjadi, banyak dari mereka tidak memilih PK. Pada Pemilu 1999, PK hanya mendapatkan $1,7 \%$ suara. $^{5}$

Melihat fakta tersebut, PK berubah menjadi PKS pada tahun 2002 kendati pun begitu bukan berarti sekedar mengganti nama saja. Tetapi PKS mengubah strategi kampanyenya, dari menyokong program Islam exclusive menjadi mendukung isu-isu yang lebih universal seperti pemerintahan bersih, anti kekerasan, dan antikorupsi. PKS berusaha keras menghindari jargon ideologis Islam. Hasilnya cukup mengejutkan! Pada pemilu 2004, partai itu berhasil 162-163.

3Damanik, dalam Suaidi Asy'ari, Nalar Politik NU dan Muhammadiyah (Yogyakarta: LKiS, 2010),

${ }^{4}$ M. Imdadun Rahmat, Ideologi Politik PKS (Yogyakarta: PT. LKIS Pelangi Aksara, 2008), 237.

${ }^{5}$ Luthfi Assyaukanie, Ideologi Islam dan Utopia (Jakarta: Freedom Institute, 2011), 254. 
meningkatkan peroleh suaranya hampir lima kali lipat yaitu menjadi 7,3\%. Banyak yang berargumen bahwa keberhasilan PKS itu bukan diakibatkan citra Islam mereka, melainkan lebih disebabkan perubahan strategi kampanye non ideologis mereka. ${ }^{6}$

Pemilu 1999 dengan nama Partai Keadilan atau PK, secara nasional memperoleh 1.436 .565 suara atau 1,4 \% (7 kursi) dan mengalami peningkatan yang sangat signifikan pada Pemilu 2004 dengan perolehan suara 8.325.020 atau $7,34 \%$ suara. Namun kemudian jumlah suara PKS menurun dalam Pemilu 2009 yang lalu, yaitu 8.206.955, walaupun prosentasenya sedikit meningkat menjadi 7,38\% karena akibat penurunan jumlah suara sah. Sebagian kalangan, baik internal PKS maupun eksternal melihat stagnasi perolehan suara PKS sebagai sinyal menguatnya dinamika internal partai itu, terutama pasca Pemilu 2004.

Penelitian tentang dinamika Partai Keadilan Sejahtera sudah pernah dilakukan beberapa peneliti, yaitu antara lain oleh Anies Baswedan, bahwa peta yang relatif lengkap tentang kiprah Islam politik di Indonesia, dari tujuh partai politik yang meraih suara signifikan dalam Pemilu 1999, Baswedan menempatkan PBB, PPP, PKS (sebelumnya PK), PKB, PAN dan Partai Golkar ke dalam kategori Islam-friendly parties, yang tidak hanya mencakup partai-partai berasas Islam, namun juga yang sensitif terhadap aspirasi umat Islam, serta didominasi oleh tokoh-tokoh yang berlatar-belakang santri. Sementara itu, PDIP dikategorikan sebagai secular-exclusive party yang menjaga jarak terhadap agenda-agenda Islam. ${ }^{8}$

Baswedan juga mengidentifikasi sejumlah karakteristik PKS. Pertama, sejak awal kiprahnya di publik politik Indonesia PKS menghindari ketergantungan pada tokoh tertentu. Kedua, PKS relatif mampu mengelola perbedaan internalnya sehingga terhindar dari perpecahan. Ciri yang pertama dan kedua ini membedakan PKS dari keenam partai lainnya. Ketiga, PKS, dan juga

\footnotetext{
${ }^{6}$ Assyaukanie.

${ }^{7}$ Arief Munandar, Antara Jemaah dan Partai Politik: Dinamika Habitus Kader PKS dalam Arena Politik Indonesia Pasca Pemilu 2004 (Disertasi, Universitas Indonesia, 2011), 1.

${ }^{8}$ Anies Rasyid Baswedan, "Politik Islam di Indonesia: Lintasan Sekarang dan Masa Depan," Jurnal Survei Asia 44, no. 5 September (2004).
} 
PAN, tidak memiliki hubungan dengan kekuatan politik masa lalu, sehingga tidak memiliki beban sejarah. Keempat, PKS, sebagaimana Golkar, PPP, dan PBB, tidak merepresentasikan salah satu dari dua organisasi Islam mainstrem: NU dan Muhammadiyah. Kelima, PKS menyiasati jumlah kursinya yang masih relatif kecil di parlemen dengan mengintensifkan aktifitas pelayanan kepada masyarakat yang kemudian diinstitusionalisasikan dalam bentuk organisasi sayap (wajihah). Keenam, berbeda dengan partai-partai lain, PKS mengakses para anggota sampai ke level terbawah sepanjang waktu, terutama melalui pertemuan rutin halaqah tiap sepekan. Pertemuan tersebut lebih dari sekedar forum untuk membahas isu-isu politik, karena juga merupakan sarana peningkatan pemahaman agama, pelibatan anggota, rekrutmen anggota baru, dan pembentukan disiplin berpartai. Ketujuh, berbeda dengan PBB dan PPP, PKS tidak berfokus pada upaya mengadopsi syariah secara formal dalam perundang-undangan, melainkan memusatkan perhatian pada dakwah untuk mengedukasi umat mengenai syariah. ${ }^{9}$

Terkait dengan ciri-ciri yang telah diuraikan di atas, Baswedan memprediksi bahwa PKS berpotensi sebagai "a major player". Lonjakan perolehan suara PKS pada Pemilu 2004 (7,34\%) dibandingkan PK tahun 1999(1,4\%) menunjukkan bahwa prediksi tersebut relatif tepat, walaupun kemudian pada Pemilu 2009 perolehan suara PKS mengalami stagnasi. Berikut ini beberapa penelitian terdahulu yang dirangkum dalam Tabel 1.

Tabel 1.

Penelitian Terdahulu

\begin{tabular}{clll}
\hline No. & \multicolumn{1}{c}{ Penulis } & \multicolumn{1}{c}{ Judul } & \multicolumn{1}{c}{ Kesimpulan } \\
\hline 1 & $\begin{array}{l}\text { Aay Muhammad } \\
\text { Furkon }\end{array}$ & $\begin{array}{l}\text { PKS: Ideologi dan Praksis } \\
\text { Politik Kaum Muda Muslim } \\
\text { Indonesia Kontemporer }\end{array}$ & $\begin{array}{l}\text { PKS tidak dapat sepenuhnya dilihat se- } \\
\text { bagai cabang (off shoot) Ikhwanul Musli- } \\
\text { min. Menurut Furkon, PKS tidak mem- } \\
\end{array}$ \\
& $(2004)$ & $\begin{array}{l}\text { punyai pemimpin atau tokoh kharismatik, } \\
\text { berbeda dengan Ikhwanul Muslimin yang }\end{array}$ \\
& & sangat bergantung pada ketokohan al- \\
& & Banna. Bagi Furkon, justru pandangan \\
& & politik PKS sejalan dengan modernisme \\
& & Islam. ${ }^{10}$ \\
\hline
\end{tabular}

${ }^{9}$ Baswedan.

${ }^{10}$ Aay Muhammad Furkon, Partai Keadilan Sejahtera: Ideologi dan Praksis Politik Kaum Muda Muslim Indonesia Kontemporer (Jakarta: Teraju, 2004). 
Mochamad Parmudi, Tulus Warsito, Sidik Jatmika

\begin{tabular}{|c|c|c|c|}
\hline 2 & Ali Said Damanik & $\begin{array}{l}\text { Fenomena Partai Keadilan: } \\
\text { Transformasi } 20 \text { tahun } \\
\text { Gerakan Tarbiyah di } \\
\text { Indonesia (2002) }\end{array}$ & $\begin{array}{l}\text { PKS adalah partai politik yang memiliki } \\
\text { akar dalam gerakan dakwah kampus. } \\
\text { Damanik berpendapat bahwa transfor- } \\
\text { masi PKS dari gerakan mahasiswa menjadi } \\
\text { gerakan politik dimungkinkan oleh dua } \\
\text { pengaruh global: revolusi Iran tahun } 1979 \\
\text { dan Ikhwanul Muslimin di Mesir. Dia } \\
\text { menyimpulkan bahwa PKS lebih dipeng- } \\
\text { aruhi oleh aktifis dan gagasan-gagasan } \\
\text { Ikhwanul Muslimin melalui tulisan-tulisan } \\
\text { para ideolog Ikhwan seperti Hassan al- } \\
\text { Banna dan Sayyid Quthub ketimbang } \\
\text { Revolusi Islam di Iran. }{ }^{11}\end{array}$ \\
\hline 3 & Arief Munandar, & $\begin{array}{l}\text { Antara Jemaah dan Partai } \\
\text { Politik: Dinamika Habitus } \\
\text { Kader PKS dalam Arena } \\
\text { Politik Indonesia Pasca } \\
\text { Pemilu } 2004\end{array}$ & 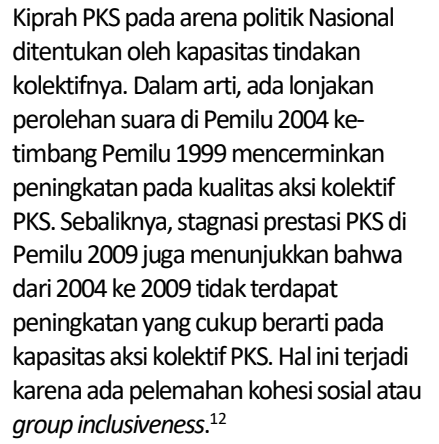 \\
\hline 4 & Burhanuddin Muhtadi & $\begin{array}{l}\text { Dilema PKS: Suara dan } \\
\text { Syariah (2012) }\end{array}$ & $\begin{array}{l}\text { Memotret fenomena PKS dari sudut } \\
\text { pandang akademis, mulai dari asal-usulnya } \\
\text { sebagai Jama'ah Tarbiyah pada masa Orde } \\
\text { Baru, pengaruh ideologis dari Ikhwanul } \\
\text { Muslimin Mesir, pendirian Partai Keadilan } \\
\text { pada awal Reformasi, sampai dinamika } \\
\text { internal antara berbagai aspirasi dalam } \\
\text { PKS. Juga, dibahas mengenai strategi PKS } \\
\text { memperjuangkan agenda politik Islamis- } \\
\text { nya di panggung politik Indonesia. }{ }^{13}\end{array}$ \\
\hline 5 & Haedar Nasir & $\begin{array}{l}\text { Gerakan Islam Syariat: Re- } \\
\text { produksi Salafiyah Ideologis } \\
\text { di Indonesia (2007) }\end{array}$ & $\begin{array}{l}\text { Bahwa Gerakan Islam di Indonesia seperti } \\
\text { memasuki fase baru. Pergeseran isu global } \\
\text { sejak tragedi } 11 \text { September telah memicu } \\
\text { artikulasi yang lebih vokal dari kelompok- } \\
\text { kelompok yang memperjuangkan } \\
\text { formalisasi agama dalam negara. Fase }\end{array}$ \\
\hline
\end{tabular}

11Damanik, Fenomena Partai Keadilan: Transformasi 20 Tahun Gerakan Tarbiyah di Indonesia.

${ }^{12}$ Munandar, Antara Jemaah dan Partai Politik: Dinamika Habitus Kader PKS dalam Arena Politik Indonesia Pasca Pemilu 2004.

${ }^{13}$ Burhanuddin Muhtadi, Dilema PKS: Suara dan Syariah Oakarta: Kepustakaan Populer Gramedia, 2012). 


\begin{tabular}{|c|c|c|c|}
\hline & & & $\begin{array}{l}\text { baru itu ditandai dengan perjuangan me- } \\
\text { lalui jalur konstitusional dengan me- } \\
\text { munculkan peraturan-peraturan (perda) } \\
\text { bernuansa syariat. Gerakan-gerakan ini } \\
\text { melirik kembali nilai-nilai ajaran salaf yang } \\
\text { dianggap sebagai solusi-kritis-tunggal } \\
\text { dengan militansi yang andal dan cermat } \\
\text { dalam beradaptasi dengan situasi yang } \\
\text { terus berubah. Gerakan tersebut juga } \\
\text { terjadi pada partai politik, salah satunya } \\
\text { PKS. }{ }^{14}\end{array}$ \\
\hline 6 & Nasiwan & $\begin{array}{l}\text { Dilema Transfromasi Partai } \\
\text { Keadilan Sejahtera (2015) }\end{array}$ & $\begin{array}{l}\text { Transformasi dari Gerakan Jemaah } \\
\text { Tarbiyah menjadi partai politik dipeng- } \\
\text { aruhi oleh dua faktor, faktor internal } \\
\text { (Corak pemahaman Islam-ideologinya } \\
\text { tidak memisahkan antara Islam dan Politik; } \\
\text { sosial dan jaringan dakwah, dan kader } \\
\text { militant) dan faktor eksternal (political } \\
\text { opportunity). Transformasi yang dihadapi } \\
\text { oleh gerakan ini baik internal maupun } \\
\text { eksternal adalah transformasi terbatas dan } \\
\text { memicu dilemma bagi Partai Keadilan } \\
\text { Sejahtera. Ada tiga level dilema yaitu } \\
\text { dilema doktrin, strategi dan outcomes } \\
\text { (muwashafat). Ada kecenderungan } \\
\text { discontinuity process antara pemahaman } \\
\text { dalam ranah keyakinan (ideologi) yang } \\
\text { komplek dan pemahaman dalam ranah } \\
\text { politik yang pragmatis. Transformasi yang } \\
\text { tergantung pada kegiatan tarbiyah dan } \\
\text { menggunakan political opportunity yang } \\
\text { sudah ada tidak mampu mendapatkan } \\
\text { dukungan yang signifikan dari Gerakan } \\
\text { Jemaah Tarbiyah. }{ }^{15}\end{array}$ \\
\hline 7 & Pradana Boy & $\begin{array}{l}\text { “Menakar Komitmen } \\
\text { Peaceful Way Hizbut Tahrir } \\
\text { Indonesia dalam } \\
\text { Konsolidasi Demokrasi,” } \\
\text { (2013) }\end{array}$ & $\begin{array}{l}\text { Bahwa salah satu ekspresi politik umat } \\
\text { Islam Indonesia yang dewasa ini tengah } \\
\text { berkembang adalah model Islamis- } \\
\text { formalis. Model politik ini mengedepankan } \\
\text { simbol-simbol keislaman dalam aktivitas } \\
\text { politik dan sering mengeksploitasi doktrin- } \\
\text { doktrin agama untuk kepentingan politik } \\
\text { praktis. Umumnya, gerakan-gerakan } \\
\text { politik seperti ini menjadikan formalisasi } \\
\text { syariah sebagai tujuan utamanya. Dengan }\end{array}$ \\
\hline
\end{tabular}

${ }^{14}$ Haedar Nasir, Gerakan Islam Syariat: Reproduksi Salafiah Ideologis di Indonesia (Jakarta: Pusat Studi Agama dan Peradaban (PSAP), 2007).

${ }^{15}$ Nasiwan, "Dilema Transformasi Partai Keadilan Sejahtera (PKS)" (Disertasi, Universitas Gadjah Mada, 2015). 


\begin{tabular}{|c|c|c|c|}
\hline & & & $\begin{array}{l}\text { mengambil contoh kasus Partai Keadilan } \\
\text { Sejahtera (PKS) dan Hizbut Tahrir } \\
\text { Indonesia (HTI), tulisan ini berpendapat } \\
\text { bahwa pada masa-masa mendatang, } \\
\text { politik kelompok Islamis akan mengalami } \\
\text { tantangan serius, dan karena itu ke- } \\
\text { mungkinan untuk gagal jauh lebih besar } \\
\text { ketimbang berhasil. Salah satu alasannya } \\
\text { adalah trauma terhadap politik aliran yang } \\
\text { hanya memperkeruh ketegangan, di- } \\
\text { tambah dengan trauma atas kepemimpin- } \\
\text { an nasional yang tidak efektif, menjadikan } \\
\text { masyarakat lebih cenderung menentukan } \\
\text { kepemimpinan berbasis kinerja. }{ }^{16}\end{array}$ \\
\hline 8 & Yon Machmudi & $\begin{array}{l}\text { Partai Keadilan Sejahtera: } \\
\text { Wajah Baru Islam Politik } \\
\text { Indonesia, Syaamil Cipta } \\
\text { Media, 2006. }\end{array}$ & $\begin{array}{l}\text { Sejarah panjang PKS: halaqah yang } \\
\text { berlanjut dengan organisasi mahasiswa, } \\
\text { Forum Silaturahmi Lembaga Dakwah } \\
\text { Kampus (FSLDK) yang membidani } \\
\text { Kesatuan Aksi Mahasiswa Muslim } \\
\text { Indonesia (KAMMI) menjelang Reformasi } \\
\text { 1998, dan akhirnya mendirikan Partai } \\
\text { keadilan (PK) pada tanggal } 28 \text { Juli } 1998 \\
\text { yang berubah nama menjadi Partai } \\
\text { Keadilan Sejahtra (PKS) pada tanggal } 20 \\
\text { April 2003. Intinya, Machmudi } \\
\text { memfokuskan kajian pada asal-usul, } \\
\text { ideology, dan pengaruh PKS terhadap } \\
\text { Islam di Indonesia. la menyatakan bahwa: } \\
\text { "PKS tidak berupaya mengusung } \\
\text { penerapan syariah melainkan mencoba } \\
\text { merevisi citra partai dengan mencurahkan } \\
\text { energy pada isu-isu keadilan dan } \\
\text { kesejahteraan. }{ }^{17}\end{array}$ \\
\hline 9 & M. Faishal Aminudin, & $\begin{array}{l}\text { Reorganisasi Partai Keadilan } \\
\text { Sejahtera di Indonesia." } \\
\text { (2010) }\end{array}$ & $\begin{array}{l}\text { Mengeksplorasi reorganisasi PKS pada } \\
\text { periode-periode penting perjalanan partai, } \\
\text { bahwa perubahan nama dari PK menjadi } \\
\text { PKS yang membawa perubahan tipologi } \\
\text { fundamental dari partai dakwah menjadi } \\
\text { partai yang berbasis mobilisasi massa } \\
\text { untuk reorganisasi partai. Pada periode } \\
\text { perubahan tersebut, PKS sukses dalam } \\
\text { mengatur ideologi dan jaringan dengan } \\
\text { unsur-unsur politik lainnya. PKS menjadi }\end{array}$ \\
\hline
\end{tabular}

${ }_{16}$ Pradana Boy, "Menakar Komitmen Peaceful Way Hizbut Tahrir Indonesia dalam Konsolidasi Demokrasi," Jurnal Maarif Institute 8, no. 2 (2013).

17Yon Machmudi, PKS: Wajah Baru Islam Politik Indonesia (Bandung: Syaamil Cipta Media, 2006). 


\begin{tabular}{lll}
\hline & & salah satu partai di Indonesia yang \\
& & berpengaruh di masa yang akan datang. ${ }^{18}$ \\
\hline 10 Teguh Imansyah & Regulasi Partai Politik dalam & Realitas yang berkembang saat ini \\
& Mewujudkan Penguatan & menunjukan lemahnya kelembagaan \\
Peran dan Fungsi & partai yang ada saat ini. Keadaan tersebut \\
Kelembagaan Partai & terlihat dari menurunnya tingkat \\
Politik." (2012). & kepercayaan terhadap partai dan \\
& maraknya kasus pelanggaran hukum yang \\
& terjadi pada para kader partai. \\
& Permasalahannya adalah bagaimana \\
& regulasi sistem kepartaian yang ada dalam \\
& membentuk kelembagaan partai untuk \\
& memenuhi fungsinya sebagai partai politik \\
& sesuai dengan undang-undang. Regulasi \\
& kepartaian yang ada belum berpengaruh \\
& signifikan dalam penguatan kelembagan \\
& partai. Lemahnya kelembagaan partai \\
& yang ada saat ini lebih disebabkan oleh \\
& sistem internal partai yang belum \\
& modern. ${ }^{19}$ \\
\hline
\end{tabular}

PKS di Kabupaten Kebumen dapat dikatakan cukup fenomenal karena perolehan suara cukup signifikan dari Pemilu 1999, 2004, 2009, dan 2014 sehingga menjadikan keunikan ketimbang penelitian-penelitian tersebut di atas.

Penelitian ini merupakan studi fenomenologis PKS di Kabupaten Kebumen tahun 1999-2014. Dalam konteks politik lokal Kebumen, PKS pada Pemilu 1999 dan 2004 belum bisa meraih kursi, baru pada Pemilu 2009 PKS memperoleh 2 kursi. Baru kemudian pada Pemilu 2014 perolehan kursi bertambah menjadi 3. Uniknya ketiga kursi anggota DPRD Kebumen dari PKS itu diduduki oleh perempuan yang cukup fenomenal yaitu: Erni Kristanti, 1774 suara (Dapil I: Kebumen dan Buluspesantren), Herni Ning Susanti, 2663 suara (Dapil II: Kutowinangun, Alian, Sadang, Poncowarno), dan Nur Hidayati, 2897 suara (Dapil III: Ambal, Mirit, Prembun, Bonorowo, Padureso).

Secara sosiologis masyarakat Kebumen didominasi kaum Santri (Nahdliyin) dan Abangan. Dominasi kaum Nahdliyin seharusnya menjadikan Partai

${ }^{18}$ Faishal Aminuddin, "Reorganisasi Partai Keadilan Sejahtera di Indonesia," Jurnal Studi Pemerintahan 1, no. 1 (2010): 141-57, http://journal.umy.ac.id/index.php/jsp/article/view/182.

${ }^{19}$ Teguh Imansyah, "Regulasi Partai Politik dalam Mewujudkan Penguatan Peran dan Fungsi Kelembagaan Partai Politik," Jurnal Rechts Vinding: Media Pembinaan Hukum Nasional 1, no. 3 (2012): 375-95, http://rechtsvinding.bphn.go.id/ejournal/index.php/jrv/article/view/91. 
Kebangkitan Bangsa yang notabene partainya Nahdlatul Ulama mendapatkan suara besar, begitu juga kaum Abangan sebagai kelompok Muslim yang tidak terlalu peduli pada praktik formal agama, berbeda dengan santri, Muslim abangan sebagian besar tinggal di daerah pedesaan sebagai petani. Dalam politik, mereka cenderung mendukung partai-partai "sekular" atau non-religius seperti Partai Nasionalis Indonesia (PNI), Partai Sosialis Indonesia (PSI), dan Partai Komunis Indonesia (PKI). ${ }^{20}$

Kemenangan dalam pemilihan Bupati Kebumen dengan mengusung pasangan H. Buyar Winarso, SE dan Djuwarni, B.A. merupakan bukti bahwa PKS telah berproses dan kemudian diterima di masyarakat. Keberadaan PKS di Kabupaten Kebumen merupakan hal yang menarik untuk dikaji, dikarenakan adanya gap yang terjadi atas kelahiran PKS di Kabupaten Kebumen. PKS merupakan salah satu partai politik berazaskan Islam dengan stigma "Wahabi". ${ }^{21}$

Berangkat dari persoalan tersebut di atas maka penulis tertarik untuk mengkaji "keajaiban" PKS dalam penelitian ini. Tujuan penelitian ini untuk menjelaskan dinamika PKS dan strategi pengembangan yang menyebabkan PKS eksis di Kabupaten Kebumen. Penelitian ini diharapkan dapat memberikan manfaat sebagai baik secar akademis mamupus praktis. Secara akademis, temuan ini akan memperkaya bangunan pengetahuan (body of knowledge) sosiologi politik, khususnya mengenai organisasi (institusi) partai politik, basis sosial, strategi politik, dan pola hubungan kekuasaan (power relationship).

Kegunaan secara praktis yaitu berupa strategi pengembangan yang dapat dilakukan untuk memperkuat upaya menjadi pemimpin politik (elective political leader), termasuk di dalamnya terdapat arena kontestasi pemimpin politik secara langsung. Penelitian ini menjadi penting untuk dipakai rujukan dalam memahami gerakan sosial politik Islam khususnya PKS di Kabupaten Kebumen (elite maupun kader partai politik), senator, pejabat pemerintah (birokrat), militer maupun sipil, tokoh masyarakat, dan para pemerhati politik.

${ }^{20}$ Assyaukanie, Ideologi Islam dan Utopia, 5.

${ }^{21}$ Wahabi lebih tepatnya Wahabisme (Arab: wahhābiyah) atau Salafi adalah sebuah aliran reformasi keagamaan dalam Islam. Aliran ini berkembang oleh dakwah seorang teolog Muslim abad ke-18 yang bernama Muhammad bin Abdul Wahhab dari Najd, Arab Saudi, yang bertujuan untuk membersihkan dan mereformasi ajaran Islam kembali kepada ajaran yang sesungguhnya, berdasarkan kepada Qur'an dan Hadis (purifikasi), dari "ketidakmurnian" seperti praktik-praktik bid'ah, syirik dan khurafat. “Wahhabisme,” Wikipedia, n.d., https://id.wikipedia.org/wiki/Wahhabisme. 
Penelitian ini dilakukan dengan menggunakan metode kualitatif. Sumber utama adalah studi pustaka (library research) dan lapangan. Penelitian lapangan (field research) dilakukan untuk memperoleh materi-materi penting seperti dokumentasi, arsip, jurnal, buku, dan sebagainya. Dengan menggunakan metode deskriptif-kualitatif, analisis ini mencoba menggambarkan dan menguraikan keadaan suatu objek berdasarkan fakta-fakta yang nampak atau sebagaimana apa adanya. ${ }^{22}$ Penelitian ini juga menggunakan pendekatan fenomenologis dimaksudkan untuk meneliti data menurut bentuk-bentuk penampakannya. Fenomenologis menunjukan proses "menjadi" dan kemampuan mengetahui gejala yang nampak secara bertahap untuk menuju pengetahuan (makna) yang benar dari objek yang diamati. Jadi, dengan metode ini diharapkan akan memperoleh interpretasi tentang dinamika perempuan berpolitik dalam strategi pengembangan Partai Keadilan Sejahtera di Kabupaten Kebumen Era Reformasi, yakni dalam rentang tahun 1999-2014.

\section{B. Perempuan Berpolitik}

Kiprah perempuan dalam dunia politik di Kebumen sangat menarik dalam perhatian penulis. Kabupaten Kebumen pernah dipimpin oleh Bupati perempuan pertama di era reformasi (Dra. Hj. Rustriningsih, M.Si.) selama dua periode tahun 2000-2005, dan terpilih kembali secara langsung untuk periode tahun 2005-2010. Pada tahun 2008 terpilih menjadi Wakil Gubernur Jawa Tengah berpasangan dengan Gubernur Bibit Waluyo. Dalam konteks sosial politik munculnya Rustriningsih, ketika itu dominasi budaya patriarki di Indonesia sangat membatasi peluang perempuan secara umum untuk terjun ke dunia politik, atau lebih jauh lagi memegang tampuk kepemimpinan politik. Berdasarkan budaya ini, kaum laki-laki lebih dilegitimasikan dalam politik dan hukum.

Hubungan perempuan dan politik tidak lepas dari image dan konstruksi sosial perempuan dalam relasi masyarakat. Image yang selama ini muncul di benak masyarakat adalah perempuan 'tidak layak' masuk dunia politik karena politik itu kejam, keras, dan penuh dengan intrik, yang hal itu hanya layak dan bisa dipenuhi oleh kaum laki-laki. Dalam konteks perpolitikan Indonesia saat

${ }^{22}$ Hadari Nawawi, Metode Penelitian Bidang Sosial (Yogyakarta: Gadjah Mada University Press, 1998), 63-64. 
ini, naiknya perempuan sebagai pemimpin politik (kepemimpinan lokal ataupun nasional) diwarnai pro-kontra karena adanya budaya patriarki, nilainilai sosial, dan justifikasi ajaran agama. Hal ini secara langsung atau tidak langsung, membatasi kiprah perempuan. Struktur dan sistem politik (sistem pemilu) sengaja atau tidak, diciptakan oleh laki-laki untuk laki-laki. Kecenderungan dalam budaya patriarki adalah bahwa tokoh politik perempuan (yang berkiprah di ranah publik) juga harus dapat mempertahankan keharmonisan rumah tangganya. Dalam arti, peran politik diperbolehkan sejauh fungsi rumah tangga tetap bisa berjalan seperti biasa.

Fakta sosial politik di Kebumen dalam Pemilu Legislatif 2014 bahwa daftar pemilih tetap berjumlah 1.034 .732 yang terdiri dari pemilih laki-laki 520.305 dan perempuan 514.427. Menurut Yulianto, M.Kom., anggota KPUD Kebumen, jumlah pemilih tersebut tersebar di 460 desa/kelurahan, dengan jumlah 3.014 TPS. Hasil Pemilu Legislatif 2014 Kabupaten Kebumen dikejutkan dengan fenomena keterpilihan tiga perempuan sekaligus dari PKS. Hal ini menjadikan prestasi tersendiri bagi PKS karena keterwakilan kader perempuannya tak tertandingi oleh parpol lainnya (PDIP: 2, Gerindra: 2, Nasdem: 2, Golkar: 2, PD: 1, PAN: 1).

Adapun nama-nama anggota DPRD Kebumen dari PKS periode 20142019 yaitu: 1) Ermi Kristanti;1.774 suara dari daerah pemilihan meliputi Kebumen dan Buluspesantren. 2) Herni Ning Susanti; 2.663 suara dari dapil 2 meliputi Kutowinangun, Alian, Sadang, Poncowarno, Karangsambung. 3) Nur Hidayati 2.897 suara dari dapil 3 meliputi Ambal, Mirit, Prembun, Bonorowo, dan Padureso.

\section{PKS sebagai Gerakan Sosial dan Politik}

Apabila PKS Kebumen merupakan organisasi gerakan sosial (lihat bagan sub judul D.kerangka berpikir) maka eksistensinya bisa dijelaskan dengan empat faktor yaitu: pertama, political opportunity strutucture (struktur kesempatan politik). Bahwa PK(S) pusat muncul bermula dari adanya situasi kondisi kegaduhan sosial dan politik (runtuhnya rezim Orde Baru) yang membuka celah struktur kesempatan politik. Adanya kebijakan konstitusi: UUD 1945, UU No. 3 Tahun 1999 tentang Pemilu, dan Undang-Undang No. 2 Tahun 2008 tentang Kepartaian. Kedua, resource mobilization (mobilisasi sumber daya). Dalam hal ini, PKS Kebumen dapat memanfaatkan struktur kesempatan 
politik melalui mobilisasi sumber daya manusia (pendiri PKS Kebumen: Drs. Rahadi, Haryoko, S.Pd., Abdul Choliq, S.Kom. dan Drs. Mundzir Hasan merupakan aktivis Lembaga Dakwah Kampus), termasuk jejaring organisasi dan sumber dananya dalam rangka mendukung kesinambungan organisasi tersebut. Ketiga, collective action framing (pembingkaian aksi kolektif). Di sini PKS secara sadar merespon atas terbukanya kesempatan politik dan peningkatan kapasitas organisasi dan infrastruktur untuk memobilisasi kader dengan menggunakan nilai-nilai keagamaan, keyakinan, budaya dan ideologi yang bisa diterima bersama. Keempat, Religious Movement (Gerakan sosial keagamaan). PKS Kebumen tidak bisa terlepas dari kebijakan institusi pusat yaitu adanya framing (pembingkaian) isu-isu transnasional Islamis. Dalam hal ini, gerakan sosial keagamaan sebagai strategi politik PKS Kebumen melalui majelis taklim, halaqah, liqo, dan sebagainya. Tujuannya menjelaskan kepada masyarakat Kebumen bahwa PKS adalah partai politik yang mengusung ideologi Islam. Secara singkat, bahwa PKS adalah partai politik yang dilahirkan melalui rahim gerakan sosial Islam yaitu Jama'ah Tarbiyah.

Dengan kata lain, tidak ada perbedaan antara PKS dan Jama'ah Tarbiyah. (Partai adalah Jama'ah, dan Jama'ah adalah Partai). PKS mengambil bentuk gerakan sosial keagamaan karena PKS tidak hanya mengartikulasikan agenda politiknya di dalam institusi partai yang terlembaga secara formal, akan tetapi juga menyatakan, mengekspresikan kepentingan politiknya melalui serangkaian aksi kolektif yang diikuti oleh para kader dan simpatisannya dan dilakukan secara regular.

\section{Dinamika Politik Lokal Kebumen}

Jumlah penduduk laki-laki sebanyak 581.947 jiwa dan perempuan sebanyak 581.644 jiwa. Jika dilihat dari persebaran penduduk, maka penduduk terbanyak berada di Kecamatan Kebumen, yaitu sebesar 10,24\%, dan penduduk paling sedikit di Kecamatan Padureso sebesar 1,13\% dari penduduk Kabupaten Kebumen (1.163.591 jiwa). Menurut kategori umur, penduduk di bawah 15 tahun sebesar 27,50\% (319.987 jiwa) dan penduduk 65 tahun ke atas sebesar 8,73\% (101.581 jiwa), sedangkan penduduk yang berumur kisaran 15 tahun sampai dengan 65 tahun yaitu 63,77\% atau 742.022 jiwa.

Awal era reformasi menjadi salah satu momentum kebangkitan partai berhaluan Islam, meskipun direpresentasikan oleh partai berbasis massa Islam 
dan partai berasas Islam, mulai dari PPP, PBB, PKB, PAN, PK, PNU, PKNU, PSII, Masyumi dan lain sebagainya. Pada pemilu 1999 yang merupakan pemilu pertama era reformasi, di Kabupaten Kebumen, PDI-P yang dianggap mewakili kalangan abangan mendapatkan dukungan 38,3\% (16 kursi) disusul dua partai yang banyak didukung kalangan Islam "tradisional” yaitu PKB 21,2\% (9 kursi) dan PPP 12,2\% (7 kursi) Golkar yang sering dianggap mewakili kelompok priyayi meraih 12,1\%; (5 kursi), PAN yang dianggap representasi kalangan Islam "modernis" meraih dukungan 5,2\%; (1 kursi), sedangkan Partai Keadilan belum bisa menduduki kursi DPRD Kebumen. (lihat Gambar1)

Pemilihan bupati Kebumen periode tahun 2000-2005 dimenangkan oleh pasangan Dra. Hj. Rustriningsih dan KH Nashirudin al Manshur yang diusung oleh PDIP. Secara politik dominasi kelompok "abangan" dan "Nahdliyin" sangat kuat baik itu di parlemen maupun di eksekutif. Realitas sosial politik Kebumen direpresentasikan oleh figure kepemimpinan daerah dari kader PDIP dan PKB.

Pada pemilu legislatif 2004 dominasi PDIP semakin kuat karena perolehan kursi DPRD II Kebumen meningkat menjadi 19 kursi, kendatipun ada penurunan pada PKB yaitu dari 9 kursi menjadi 7 kursi. Kendatipun begitu pada pemilihan Bupati periode 2005-2010 secara langsung pasangan Dra $\mathrm{Hj}$. Rustriningsih dengan KH Nashirudin yang diusung PDIP dan PKB kembali memperoleh kepercayaan masyarakat Kebumen dengan memenangi kompeti-

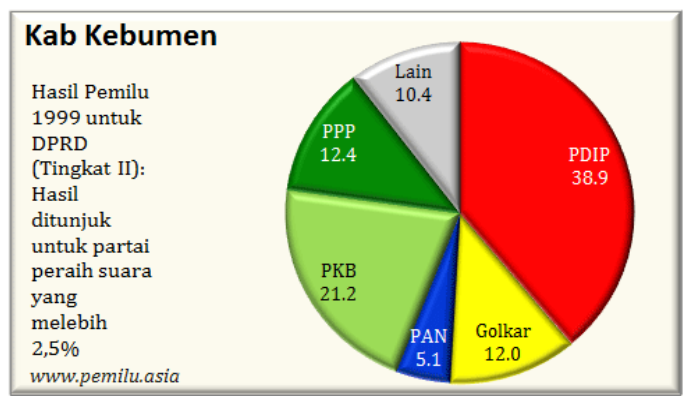

Gambar 1.

Dominasi Perolehan Kursi Legislatif Th.1999 
petisi pemilihan kepala daerah yang kedua kalinya. Tetapi pada periode kedua tidak terselesaikan karena Rustriningsih terpilih menjadi Wakil Gubernur Jawa Tengah, mendampingi Bibit Waluyo, untuk periode tahun 2008-2013.

Dinamika politik lokal Kebumen pada tahun 2009 terlihat dari hasil pemilu legislatif yaitu menurunnya perolehan suara PDIP menjadi 15 kursi kendatipun masih sebagai pemenang pemilu. Adapun PKB memperoleh kursi 5, PAN meraih 3 kursi, sedangkan PKS baru bisa menduduki 1 kursi. Pada pemilihan bupati 2010-2015 koalisi "partai islam" berhasil memenangi kontestasi demokrasi secara dramatis (dua putaran) dengan mengusung pasangan Buyar Winarso dan Djuwarni yang mengalahkan pasangan KH Nashiruddin dan Probo Indartono yang diusung oleh koalisi "Nahdliyin dan Abangan”.

Kemudian pada tahun 2014 fenomena politik Kebumen berubah secara cukup signifikan karena kendatipun dominasi kaum abangan masih terlihat kuat, akan tetapi mulai menurun drastis yaitu karena perolehan kursi PDIP menjadi 9 kursi. Sedangkan perolehan kursi PKS menjadi 3 kursi yang uniknya ketiga kursi itu diduduki oleh kader-kader perempuan. Ketika pemilihan Bupati periode 2015-2020 pasangan calon bupati yang diusung PDIP dapat dikalahkan oleh koalisi PAN, PKB, PPP dan Gerindra. Peningkatan perolehan suara dan kursi PKS pada pemilu 2014 walaupun "sedikit", akan tetapi secara politik lokal Kebumen menandakan bahwa PKS semakin mendapatkan kepercayaan dari masyarakat Kebumen.

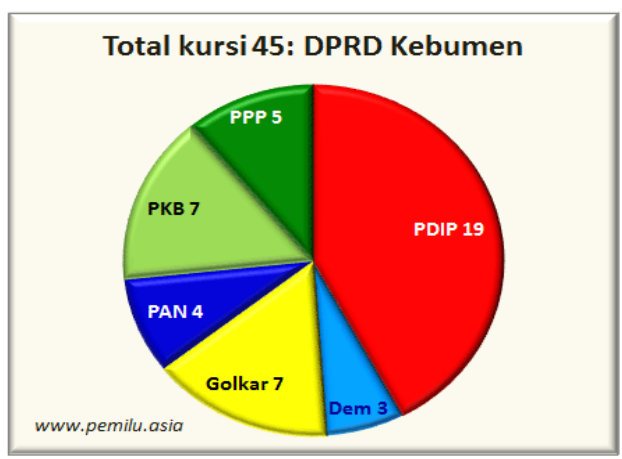

Gambar 2.

Dominasi Perolehan Kursi Legislatif Th.2004 


\section{E. Implikasi Teoritik}

Tabel 2.

Eksistensi PKS Kabupaten Kebumen sebagai Gerakan Sosial

\begin{tabular}{|c|c|c|c|c|c|}
\hline \multicolumn{2}{|r|}{$\begin{array}{l}\text { Partai Kader (Ciri } \\
\text { Umum) }\end{array}$} & $\begin{array}{l}\text { Temuan (pendukung) } \\
\text { Perolehan suara; } \\
\text { Tahun 1999: } 4244 \\
\text { Tahun 2004: } 20965\end{array}$ & \multicolumn{2}{|c|}{$\begin{array}{c}\text { Partai Kader Berbasis } \\
\text { Gerakan Keagamaan } \\
\text { (Ciri Khusus) }\end{array}$} & \multirow[b]{2}{*}{$\begin{array}{l}\quad \begin{array}{c}\text { Temuan } \\
\text { (pendukung) }\end{array} \\
\begin{array}{l}\text { Pemilihan format } \\
\text { terbuka. Muncul }\end{array} \\
\text { Faksionalisasi } \\
\text { Harakah versus } \\
\text { Hizb. “Gerakan } \\
\text { Dakwah" dengan } \\
\text { doktrin “(jama'ah } \\
\text { adalah partai, dan } \\
\text { partai adalah } \\
\text { jama'ah), serta azas } \\
\text { Islam yang } \\
\text { termaktub dalam } \\
\text { Anggaran Dasar } \\
\text { /Aanggaran Rumah } \\
\text { Tangga. }\end{array}$} \\
\hline 1 & $\begin{array}{l}\text { Basis sosial: } \\
\text { muslim, kota, } \\
\text { terdidik \& } \\
\text { muda. } \\
\text { konstituen } \\
\text { pemilih yang } \\
\text { relatif kecil }\end{array}$ & $\begin{array}{l}\text { Perolehan suara; } \\
\text { Tahun 1999: } 4244 \\
\text { Tahun 2004: } 20965 \\
\text { Tahun 2009: } 29569 \\
\text { Tahun 2014: } 50355\end{array}$ & 1 & $\begin{array}{l}\text { Dominasi } \\
\text { ideologi Islam }\end{array}$ & \\
\hline 2 & $\begin{array}{l}\text { Strategi } \\
\text { pengembangan } \\
\text { /perluasan } \\
\text { basis pemilih }\end{array}$ & $\begin{array}{l}\text { Wacana menjadi } \\
\text { Partai Terbuka } \\
\text { (inklusif), Tagline yang } \\
\text { "ngepop" dan } \\
\text { kontroversial, } \\
\text { misalnya: "Biar } \\
\text { Kempes Tetep PKS", } \\
\text { PKS: Partai Kita } \\
\text { Semua. Munas di Bali } \\
\text { (2009) }\end{array}$ & 2 & $\begin{array}{l}\text { Struktur } \\
\text { organisasi yang } \\
\text { cenderung } \\
\text { Oligarkis }\end{array}$ & $\begin{array}{l}\text { Ketua Majelis Syura } \\
\text { atau Murraqib 'Am } \\
\text { dan Dewan } \\
\text { Pimpinan Tingkat } \\
\text { Pusat atau Majelis } \\
\text { Riqabah 'Ammah } \\
\text { yang memiliki } \\
\text { otoritas yang sangat } \\
\text { besar }\end{array}$ \\
\hline 3 & $\begin{array}{l}\text { Struktur } \\
\text { organisasi } \\
\text { hirarkhis, } \\
\text { vertikal yang } \\
\text { kuat }\end{array}$ & $\begin{array}{l}\text { Dewan Pimpinan } \\
\text { Pusat (DPP), Dewan } \\
\text { Pimpinan Wilayah } \\
\text { (DPW), DPD } \\
\text { (Kabupaten/Kota), } \\
\text { DPC (Kecamatan), dan } \\
\text { DPRa (Kelurahan/ } \\
\text { Desa) }\end{array}$ & 3. & $\begin{array}{l}\text { Mekanisme } \\
\text { "demokrasi } \\
\text { terbatas" untuk } \\
\text { mewadahi } \\
\text { partisipasi akar } \\
\text { rumput. }\end{array}$ & $\begin{array}{l}\text { Pemilihan raya } \\
\text { untuk memilih } \\
\text { sebagian dari } \\
\text { anggota Majelis } \\
\text { Syura yang mewakili } \\
\text { para kader di } \\
\text { seluruh Indonesia }\end{array}$ \\
\hline 4 & $\begin{array}{l}\text { Kombinasi dana } \\
\text { taktis, sumber } \\
\text { finansial dari } \\
\text { anggota dan } \\
\text { publik }\end{array}$ & $\begin{array}{l}\text { luran Anggota, } \\
\text { potongan gaji anggota } \\
\text { legislatif, dan pejabat } \\
\text { publik dari PKS, dana } \\
\text { aspirasi; subsidi } \\
\text { negara, donatur }\end{array}$ & 4. & $\begin{array}{l}\text { Sistem } \\
\text { kaderisasi yang } \\
\text { ketat, selektif, } \\
\text { dan berjenjang. }\end{array}$ & $\begin{array}{l}\text { Sistem tarbiyah } \\
\text { dengan enam level } \\
\text { keanggotaan dan } \\
\text { mekanisme taqwim } \\
\text { (evaluasi) kenaikan } \\
\text { level. }\end{array}$ \\
\hline
\end{tabular}

Sumber Data: Diolah dari Berbagai Sumber 
Berdasarkan uraian kerangka teoritik yang meliputi basis sosial, strategi politik, dan pendekatan integrasi gerakan sosial maka implikasi teoriknya adalah bahwa PKS tidak lahir sebagai representasi dari sebuah kelas sosial tertentu, melainkan dari sebuah ideologi, atau pemikiran keagamaan Islam. Realita sosial dan politik dengan sistem demokrasi yang berlangsung saat ini, maka PKS untuk bisa eksis harus memperluas basis sosial pemilihnya, sekaligus menerapkan strategi politiknya yang relevan dan dinamis. Gambaran implikasi teoritiknya dapat dilihat pada Tabel 2.

Kemudian sebagai implikasi teoritik strategi politik pengembangan PKS di Kabupaten Kebumen dalam perolehan kursi di DPRD Kabupaten Kebumen dapat diilustrasikan secara sederhana dalam Tabel 3. Adapun gerakan kader PKS Kebumen di era reformasi dapat dilihat pada Tabel 4.

Tabel 3.

Ilustrasi Strategi Peerolehan Kursi PKS Kebumen

\begin{tabular}{|c|c|c|c|c|c|}
\hline No. & Strategi Gerakan/Respon Isu & $\begin{array}{c}\text { PK } \\
1999\end{array}$ & $\begin{array}{c}\text { PKS } \\
2004\end{array}$ & $\begin{array}{c}\text { PKS } \\
2009\end{array}$ & $\begin{array}{c}\text { PKS } \\
2014\end{array}$ \\
\hline 1 & $\begin{array}{l}\text { Ofensif (sosialisasi atribut PKS), Majelis Taklim, } \\
\text { Respon Islam Radikal, Wahabisme, Bakti sosial, } \\
\text { Bantuan Bencana Alam }\end{array}$ & 0 & & & \\
\hline 2 & $\begin{array}{l}\text { Ofensif, Majelis Taklim, Respon Islam Radikal, } \\
\text { Wahabisme, Bakti sosial, Bantuan Bencana Alam, } \\
\text { Bantuan Pendidikan }\end{array}$ & & 0 & & \\
\hline 3 & $\begin{array}{l}\text { Ofensif, Strukturisasi, Kaderisasi, Majelis Taklim, } \\
\text { Respon Islam Radikal, Wahabisme, Bakti sosial, } \\
\text { Bantuan Bencana Alam, Bantuan Pendidikan, } \\
\text { Inklusivisme, Pola Komunikasi Politik }\end{array}$ & & & 2 & \\
\hline 4 & $\begin{array}{l}\text { Ofensif, Strukturisasi, Kaderisasi, Majelis Taklim, } \\
\text { Respon Islam Radikal, Wahabisme, Bakti sosial, } \\
\text { Bantuan Bencana Alam, Bantuan Pendidikan, } \\
\text { Inklusivisme, Ta'awun (Bantuan Pinjaman } \\
\text { Finansial), Kuota Perempuan }\end{array}$ & & & & 3 \\
\hline
\end{tabular}


Mochamad Parmudi, Tulus Warsito, Sidik Jatmika

Tabel 4.

Mobilitas Kader PKS Kebumen di Era Reformasi

\begin{tabular}{|c|c|c|c|c|c|c|}
\hline No. & $\begin{array}{c}\text { Gerakan } \\
\text { Perluasan } \\
\text { Jaringan }\end{array}$ & Rahadi & Suratno & $\begin{array}{c}\text { Ermi } \\
\text { Kristanti }\end{array}$ & $\begin{array}{l}\text { Herni Ning } \\
\text { Susanti }\end{array}$ & $\begin{array}{c}\text { Nur } \\
\text { Hidayati }\end{array}$ \\
\hline \multirow[t]{6}{*}{1} & Modal Awal, & Harta & Harta & Harta & Harta & Harta \\
\hline & Ekonomi, & Keluarga & Keluarga, & Keluarga & Keluarga, & Keluarga \\
\hline & Kultural & Penghasilan & Penghasilan & Penghasilan & Penghasilan & Penghasilan \\
\hline & & Pekerjaaan & Pekerjaaan & Pekerjaaan & Pekerjaaan & Pekerjaaan \\
\hline & & Guru, S1 & Driver, SMU & $\mathrm{S} 2$ & S1 & Konsultan; \\
\hline & & & & & & S1 \\
\hline \multirow[t]{3}{*}{2} & Jaringan Ormas/ & Muhammadiy & Serikat & Ikatan Istri & Pengurus DPC & Pengurus \\
\hline & Islam/Sosial Lain & ah, Asosiasi & Pekerja & Dokter & PKS Kebumen & DPD PKS \\
\hline & & Guru & (Sopir) & & & Kebumen \\
\hline \multirow[t]{4}{*}{3} & Kedudukan Politik & Anggota & Anggota & Anggota & Anggota & Anggota \\
\hline & yang Dicapai & DPRD & DPRD & DPRD & DPRD & DPRD \\
\hline & & Kebumen, & Kebumen, & Kebumen, & Kebumen, & Kebumen, \\
\hline & & $2009-2014$ & 2009-2014 & 2014-2019 & 2014-2019 & 2014-2019 \\
\hline
\end{tabular}

Sumber Data: Diolah dari Berbagai Sumber

\section{F. Kesimpulan}

Berdasarkan tahap-tahap pembahasan hasil penelitian, dan merujuk pada pertanyaan pertanyaan penelitian maka diperoleh dua kesimpulan sebagai berikut: Pertama, bahwa kelahiran PKS bisa diterima dan eksis di masyarakat Kabupaten Kebumen karena PKS melakukan pendekatan ke masyarakat melalui berbagai bidang, yakni melalui kegiatan-kemasyarakatan seperti; keagamaan, pendidikan, budaya, sosial, dan ekonomi. Pendekatan tersebut dilakukan tanpa membawa misi dakwah atau membawa perbedaan faham dan murni dengan tujuan membantu masyarakat. Sehingga walaupun terjadi perbedaan faham dengan masyarakat yang notabene warga Nahdliyin, tidak menimbulkan konflik bagi eksistensi PKS di Kebumen. Hal ini juga tidak terlepas dari eksistensi PKS di Indonesia yang mengadopsi pemikiran Hasan alBanna dari Ikhwanul Muslimin di Mesir tersebut disesuaikan dengan situasi, kondisi, serta budaya di Indonesia. Eksistensi PKS Kebumen ditopang dengan basis sosialnya muslim, masyarakat kota, terdidik, muda kendatipun masih termasuk konstituen pemilih yang relatif kecil. Ini terbukti dengan dukungan perolehan suara; tahun 1999: 4244, tahun 2004: 20965, tahun 2009: 29569, dan tahun 2014: 50355. Di satu sisi, PKS cerdas dalam merebut hati 
masyarakat Indonesia secara umum termasuk di Kebumen, tetapi di sisi lain, PKS di Indonesia justru kehilangan citranya sebagai partai dakwah yang berideologi Islam. Hal ini justru sedikit demi sedikit mulai melunturkan watak ideologis PKS di Indonesia. Akhirnya, PKS menjadi terlihat cenderung bersifat pragmatis (elektoralis), permisif, dan kompromis dalam berpolitik.

Kedua, PKS Kebumen menggunakan strategi menyerang (ofensif) dalam arti memobilisasi sumber daya manusia, dengan pembingkaian gerakan sosial keagamaan yang berupa aksi-aksi kolektif, strategi pengembangan menjadi Partai Terbuka (inklusif). Hal ini diekspresikan dengan tagline yang "ngepop" dan kontroversial, misalnya: "Biar kempes tetep PKS", "PKS: Partai Kita Semua”. Ini bisa memperluas basis sosial PKS Kebumen.

Temuan kebaruan penelitian ini dapat dibaca secara kombinasi (hibridasi) bahwa partai politik bisa eksis tidak hanya dengan dukungan basis sosial saja tetapi harus memiliki ideologi, dan menerapkan strategi menyerang (ofensif). Adanya struktur kesempatan politik, mobilisasi sumber daya yang dibingkai menjadi aksi kolektif, ataupun gerakan keagamaan. Kemudian ditopang dengan struktur organisasi secara vertikal yang kuat.

\section{Saran-saran}

Berdasarkan hasil penelitian, maka dapat diajukan beberapa rekomendasi sebagai berikut: Pertama, ideologi partai merupakan modal utama dalam menuju keberhasilan politik, karena itu PKS perlu mengkaji, dan menentukan kembali ideologi sebagai strategi pengembangan PKS. Peralihan ideologis menjadi pragmatis akan menimbulkan konflik di tubuh PKS. Kedua, loyalitas dan tanggung jawab kader terhadap partai untuk menjunjung tinggi ideologi partai. Oleh karena itu sebagai partai yang mempunyai basis pengkaderan seharusnya PKS tidak mudah menerima anggota baru dalam partainya, sehingga hanya dijadikan batu loncatan.[s]

\section{Daftar Pustaka}

Aminuddin, Faishal. "Reorganisasi Partai Keadilan Sejahtera di Indonesia." Jurnal Studi Pemerintahan 1, no. 1 (2010): 141-57. http://journal.umy. ac.id/index.php/jsp/article/view/182. 
Mochamad Parmudi, Tulus Warsito, Sidik Jatmika

Assyaukanie, Luthfi. Ideologi Islam dan Utopia. Jakarta: Freedom Institute, 2011. Asy'ari, Suaidi. Nalar Politik NU dan Muhammadiyah. Yogyakarta: LKiS, 2010.

Baswedan, Anies Rasyid. "Politik Islam di Indonesia: Lintasan Sekarang dan Masa Depan." Jurnal Survei Asia 44, no. 5 September (2004).

Boy, Pradana. "Menakar Komitmen Peaceful Way Hizbut Tahrir Indonesia dalam Konsolidasi Demokrasi." Jurnal Maarif Institute 8, no. 2 (2013).

Damanik, Ali Said. Fenomena Partai Keadilan: Transformasi 20 Tahun Gerakan Tarbiyah di Indonesia. Jakarta: Teraju, 2003.

Furkon, Aay Muhammad. Partai Keadilan Sejahtera: Ideologi dan Praksis Politik Kaum Muda Muslim Indonesia Kontemporer. Jakarta: Teraju, 2004.

Imansyah, Teguh. "Regulasi Partai Politik dalam Mewujudkan Penguatan Peran dan Fungsi Kelembagaan Partai Politik." Jurnal Rechts Vinding: Media Pembinaan Hukum Nasional 1, no. 3 (2012): 375-95. http://rechtsvinding. bphn.go.id/ejournal/index.php/jrv/article/view/91.

Iqbal, Muhammad, dan Amien Hussein Nasution. Pemikiran Politik Islam: dari Masa Klasik Hingga Indonesia Kontemporer. 3 ed. Jakarta: Kencana Prenada Media, 2010.

Machmudi, Yon. PKS: Wajah Baru Islam Politik Indonesia. Bandung: Syaamil Cipta Media, 2006.

Muhtadi, Burhanuddin. Dilema PKS: Suara dan Syariah. Jakarta: Kepustakaan Populer Gramedia, 2012.

Munandar, Arief. Antara Jemaah dan Partai Politik: Dinamika Habitus Kader PKS dalam Arena Politik Indonesia Pasca Pemilu 2004. Jakarta: Disertasi. Universitas Indonesia, 2011.

Nasir, Haedar. Gerakan Islam Syariat: Reproduksi Salafiah Ideologis di Indonesia. Jakarta: Pusat Studi Agama dan Peradaban (PSAP), 2007.

Nasiwan. "Dilema Transformasi Partai Keadilan Sejahtera (PKS)." Disertasi. Universitas Gadjah Mada, 2015.

Nawawi, Hadari. Metode Penelitian Bidang Sosial. Yogyakarta: Gadjah Mada University Press, 1998.

Rahmat, M. Imdadun. Ideologi Politik PKS. Yogyakarta: PT. LKiS Pelangi Aksara, 2008. 
Dinamika Perempuan Berpolitik ....

Setiawan, Bambang, dan Bastian Nainggolan. Partai-partai Politik Indonesia: Ideologi dan Program 2004-2009. Jakarta: Kompas Gramedia Group, 2004.

"Wahhabisme." Wikipedia, n.d. https://id.wikipedia.org/wiki/Wahhabisme. 
This page intentionally left blank 